\title{
Expression of Gentleman's Blood In Javanese Keris
}

\author{
Widodo Aribowo ${ }^{1}$, Andrik Purwasito ${ }^{2}$, Wakit Abdullah $^{3}$, Titis Srimuda Pitana ${ }^{4}$ \\ \{widodo_aribowo@student.uns.ac.id\}
}

Postgraduate Program in Cultural Studies, Sebelas Maret University, Jl. Ir. Sutami 36A, Surakarta

57126, Indonesia

\begin{abstract}
This study aims to answer the problem of why Java experienced such a long pause from a series of warfare until 1757. At the same time, there was prosperity in Java, which was marked by the rapid increase in agricultural production in the colonial era by the Dutch Company. The subject matter was the keris Pangeran Jimat from the era of the Demak kingdom in 1626, as well as Keris Mintaraga and Keris Rapalan. This keris was made to accompany the manufacture of the giant cannon called Ki Jimat which was used to attack the Portuguese occupation in Malacca. The historical method is used to solve this problem, especially in the prohibition of importing iron into Java. Meanwhile iron is the main ingredient in keris making. This import ban sparked the awareness of Susuhunan Pakubuwana III to stop the war that had killed so many Moslems. The stopping of the war by Company and the Mataram kingdom was based on the fact that all soldiers were warriors whose lives were very valuable. In 1757 the war ceased for a long period of time and Java achieved temporary prosperity.
\end{abstract}

Keywords: peace-lord, Javanesse keris, giant cannon, Pakubuwana III

\section{Introduction}

The Covid-19 pandemic is unable to control the war that continues to rage. Currently the war is still ongoing in several parts of the world. Based on the definition of war as: a) armed conflict between different countries or groups within a country; b) a state of competition or enmity between different people or groups; c) continuous campaign against unwanted situations or activities, at this time war still occurs in various parts of the world (worldpopulationreview.com accessed October 4, 2020). According to [1] data, the inter-state conflicts that continue to occur are Iran-Israel and India-Pakistan.

It is better if we stop for a moment, look back at the time of the Java War which lasted for 80 years. There was a period of around 60 years of peace (1757-1825) before the Diponegoro War broke out. This flashback aims to illustrate that there was a war that was caused by individual ambition and which caused massive casualties. War costs enormous amounts of human life, property and money. The formation of a military unit or armed forces is very expensive.

Therefore, there must be a sound reason for the war. That rational reason will show that the good and bad values are the basis for actions in a warfare. In contrast to the act of war, peaceful efforts will be important when war has occurred and is caused by inappropriate reasons. According to [2], one of the keys to creating peace is local leadership. Leadership itself is an intangible concept, depends on the understanding of each person, and is difficult to understand, but it exists in society. Leadership can be used to divide until conflict occurs, and in the other 
hand it can be used for a more noble purpose, particularly as a force to press towards goodness, accelerate reconciliation, cooperation, and harmony. This study presents an agency, namely Pakubuwono III, who reigned as king in the Surakarta Palace in the mid to late $18^{\text {th }}$ century.

\section{Research Methods}

This research tries to approach the phenomenon of the emergence of material culture i.e.: 1) Pangeran Jimat (a keris created during the Demak Kingdom around 1626);2) Keris Mintaraga a keris from the Hindhu period; and 3) Keris Rapalan which was created during Pakubuwono III period (1749-1788). Regarding the outbreak of the Covid-19 Pandemic, the museum prohibits tourist visits, so that material data in the museum is searched in library. The Keris Pangeran Jimat is a collection of the heirs of the Demak Sultanate, observations can only be made through photos sent via email. Keris Mintaraga is Callenfels research work (1925)[3] while Keris Rapalan (on display at the Nusantara Keris Museum in Surakarta) is contained in the book of keris[4].

This research of Cultural Studies utilized historical science as an auxiliary science to approach the phenomenon of the emergence of material culture as mentioned above. The agency as the center for building awareness was Pakubuwono III (reigned in Mataram Surakarta in 1749-1788). Suffered under strong pressure from the VOC and the situation of the Java War, our figure been the peace-lord. The historical approach is: first, using kris as a historical verified disciplinary archive [5].

Second, there is a new perspective as well as a concept of the keris as the heirloom of the knights. This new concept is a synthesis from an earlier perspective: the keris as a technical weapon (Company's perspective) and the keris as a magical heirloom (Javanese). At the time PB III wanted to create a keris in a new concept, iron as the main material for making keris was not available in Java. This is in the aftermath of the Dutch ban on iron imports in 1741. PB III keeps making keris even though it is made of "patch-up" iron. Keris made based on this concept became the prototype for the kris that emerged from the late 18th century until now.

Third, that it is necessary to collect information on how the expressions of the Javanese keris are used as a means of campaigning for peace. The war must be stopped because it has caused Muslims to be killed for unsuitable reasons related to worldly matters. The warrior group as the party who directly involved in warfare were the superior beings as best as the Muslims. Their lives are very precious and may only have their blood flowed for reasons justified by religion.

This research will present a new discovery that in the modern era (mid-18th century) the keris did not stand out as a magical and technical weapon but a beautiful heirloom as a knight's hold. The protrusion of the knights through those kerises seems to be an effective campaign mean to remind the need of halting the war. Conflict in the classical period of the Javanese kingdom may not be as complicated as that in developed countries where plurality situations are very easy to trigger conflict [6]. It is hoped that the disclosure of agency (local leadership) in creating an atmosphere of peace is expected to be able to provide another situation in 'peace research' although initially this field was opposed by academics as a "terrible word"[7]. 


\section{Results and Discussion}

\subsection{The Technical VOC and The Magical Javanesse}

Ricklefs states that the Dutch Company - VOC: Vereenigde Oost-Indie Compagnie is a Dutch trading joint venture capitalized by the Dutch Government - had participated in the Java war for 80 years since 1677, ending in 1757[8]. Initially the Dutch came to Indonesia only to trade, but the ships going to Java were equipped with armed troops. This is understandable considering, first: the world situation, especially Europe, is being ravaged by wars. In 1596 when the first Dutch ships found a "safe" shipping route to Java, the Netherlands was just breaking free from Spanish rule. Second, the shipping routes to Asia and the archipelago in particular were being controlled by the Portuguese and guarded by ships with heavy weapons such as cannons. Third, the Netherlands needed strong safeguards to anticipate violence against its fleet, considering that on the first voyage there was violence caused enmity with the local residents[9].

In early steps, the Dutch were only in the coastal areas to trade with natives and were not interested in going further inland. Spices, which were becoming valuable commodities in Europe, could be obtained easily through transactions with Indonesian traders who made transactions in ports. In the following times, the Dutch began to be interested in entering the hinterland due to several factors: 1) more secure supply; 2) get a lower price; 3) controlling trade routes and commercial shipping with Asian nations and the world; 4) want to control commodities other than spices, especially rice and teak wood[10].

The Dutch intervened in Javanese rule around the 1670s in the Trunajaya rebellion which attempted to get rid Amangkurat I. Amangkurat I was overthrown and passed away while on the run. Unfortunately, the crown prince, Amangkurat II, saved the Mataram throne for himself by asking the VOC armed forces for help. The war costs to be borne by Amangkurat II were enormous, and the price to be paid was the handing over of the ports - along with the income earned from that port - in north coast of Java to the VOC. After that period, Java was hit by a prolonged war without stopping until 1757[11].

In 1757 Mas Said - one of the warlords of the 80 years Java War - surrendered to Pakubuwono III. The Salatiga Treaty in the same year legalized the establishment of the Mangkunegaran Kadipaten which was given rights to an area of 4,000 households in southern Surakarta and established a palace in the middle of Surakarta. Java experienced a relatively long period of peace[8]. This period is 2 years since the signing of the Giyanti Agreement (13 February 1755) or called Palihan Nagari because the Mataram kingdom is divided into two equal areas, namely Surakarta and Yogyakarta. The king of Surakarta is Pakubuwono III while Yogyakarta is led by Sultan Hamengkubuwono I. The granting of power to this warlord is a series of peace efforts made by Pakubuwono III so that bloodshed that has killed so many Muslims does not occur again.

\subsection{Cannon: Technical Weapon and Keris: Magical Weapon}

Many deaths occurred during the Java War because the war units armed themselves with firearms such as cannons and muskets. The original Javanese weapons of war were keris, sword and spear. Is that the only Indonesian weapon? Certainly not. Heavy artillery such as cannons were imported in 1293, then there was a transfer of technology where the Indonesians began to be able to produce fantastic numbers of cannons by themselves. In the 15 th century, the archipelago had produced its own cannons, both iron and bronze. Albuquerque tells that in 1511 the Portuguese as the first European subjugator were able to seize 3,000 cannons $(2,000$ from bronze and 1,000 from iron) from the Nusantara troops in Malacca. The manufacturing 
technique was very good, unmatched, nor was it by the Portuguese as an expert gun maker[12]. The Javanese did own and make weapons such as musket (bedhil), small cannon (lila), and cannon, but the main weapons were still spears, keris and short swords[13].

The Javanese do not prioritize weapons as technical tools, namely the tools used by a human to kill even as many people as possible. Mataram's predecessor, the Demak Kingdom, which controlled the Java Sea and the power of war, treated the keris as a magical weapon based on the belief that human life is in the hands of God. The Javanese believe that people who have supernatural powers such as being invulnerable to weapons and other powers receive a mandate from God to enforce jihad. Jihad is not the same as killing people. People who are allowed to be killed are infidels who prevent Muslims from living in the way of Allah.

This belief underlies Demak's attack on Malacca, which was the seat of the Portuguese people. The Ki Jimat cannon became the mainstay of the attack. Ki Jimat cannon was made simultaneously with Pangeran Jimat's keris. The keris has the encryption of 'Pangeran Jimat' in the frame and Allah on the blade[14]. Caption of Figure 1.: a) Ki Jimat, also known as Ki Pamuk[15]; b) Keris Pangeran Jimat blade; c) enciption of Allah on the blade of Keris Pangeran Jimat; d) Keris Pangeran Jimat with its sheath (the keris and its photographs belong to the heirs of the Demak Sultanate and also the descendants of Mangkunegaran whose names cannot be mentioned); e) encryption "Pangeran Jimat" on the sheath of Keris Pangeran Jimat.

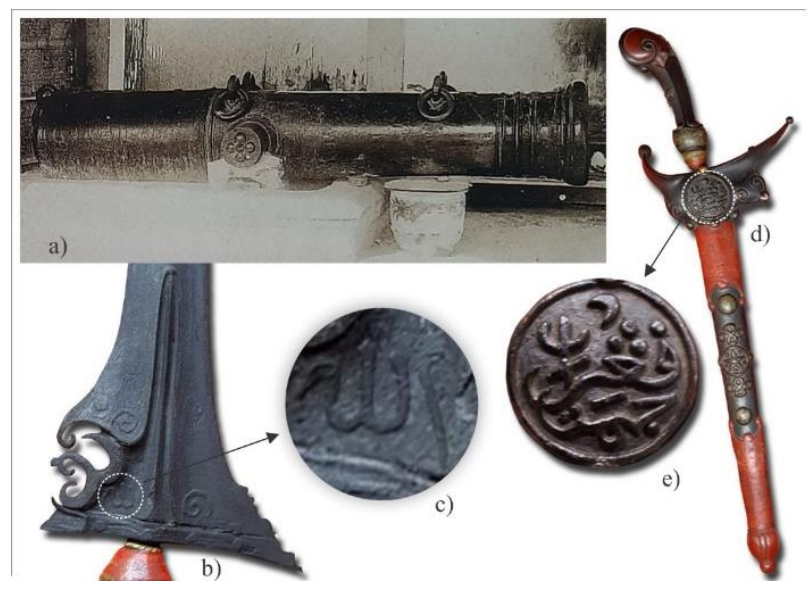

Fig 1. A cannon called Ki Jimat and Keris Pangeran Jimat:

\subsection{Peace-Lord's Talks}

PB III's apprehension at the time of the throne was the threat of Mataram disintegration because war was ravaging Java. There are 3 parties outside Mataram that are difficult to predict which side is permanently on, namely Pangeran Mangkubumi, Mas Said, and the VOC. The first and second were PB III's uncle, both of them were entitled to the throne of Mataram and then rebelled against Mataram to get their rights. Meanwhile, the latter is a European merchantstate which has a strong technical weaponry[16].

PB III looks at the era of the Kahuripan Kingdom when the palihan nagari (state splitting) occurred in 1042 which divided Kahuripan into Kediri (with a capital city in Daha) and Jenggala (with a capital city in Kahuripan)[17]. There is a trilogy of cultural-political events that accompanies the event: Kakawin Arjuna Wiwaha by Empu Kano, the visualization of Arjuna's figure into Mintaraga's keris, and the Panji Story. PB III does the same with hopes: 1) reminding that too much Muslim blood has been shed for useless wars because they are fighting over 
worldly things; 2) so that later in the event of a palihan nagari, Mataram will reunite. It can be seen that there are elements of a peace campaign using culture in PB III's perception of war[16].

A trilogy resembling the Kahuripan era made during PB III is the emergence of Serat Wiwaha Jarwa and Serat Mintaraga, Keris Rapalan, and Serat Panji. Serat Wiwaha Jarwa is written by PB III while Serat Panji is by poet court Yasadipura The Elder which is an important part of the story of the hero (prince of blood) with Arjuna and Cerita Menak[18]. The stories of Panji and Serat Panji both describe Prince Panji's wanderings and his reuniting with Princess Sekartaji. Serat Wiwaha Jarwa and Arjuna-Wiwaha Kakawin both describe Arjuna as an ascetic course with the aim of gaining supernatural powers as a great knight[19].

Pakubuwono III also made a keris called Keris Rapalan in 3 levels: 1) Kanjeng Kyai Ageng Rapal which is kept in the heirloom room as part of the inner of Javanese; 2) Kanjeng Kyai Rapal which Pakubuwono III's kingship attribute as a reminder of Allah and to prevent anger; 3) Kyai Rapal given to lords and warlords with the aim of giving emotions to the people[16]. The Rapalan keris has a distinctive appearance, especially pure gold ornaments that is engraved on the keris blade and on the ganja section which forms Arabic letters and pictures.

The Keris Mintaraga was described by Callenfels in a research report submitted to the Archaeological Service (formerly Oudkundige Dienst) in 1925[3]. In his report, Callenfels stated that this keris originated from the Hindhu era. One side of the keris shows parts of ganja starting from some clowns (punakawan) looks intimate with the inya (female servant) of the nymphs, then a temple complex with a meru roof. Meanwhile, to the left of the meru, Arjuna is sitting at the highest point, meditating as an ascetic.

Above Arjuna (also called Begawan Ciptawening) there are two standing figures, the right one is Arjuna and the left is probably Indra as the old man who visited him. In the relief, one can see a "classic" representation of the seduction scene. Then two nymphs (on the right and left of Arjuna who were sitting in a yoga position) were seen, trying to seduce the hermit. The peak of the overall glory is the pendapa with the meru roof, the roof top is completed with flying ribbons, just like in Indra's heavenly palace[3].

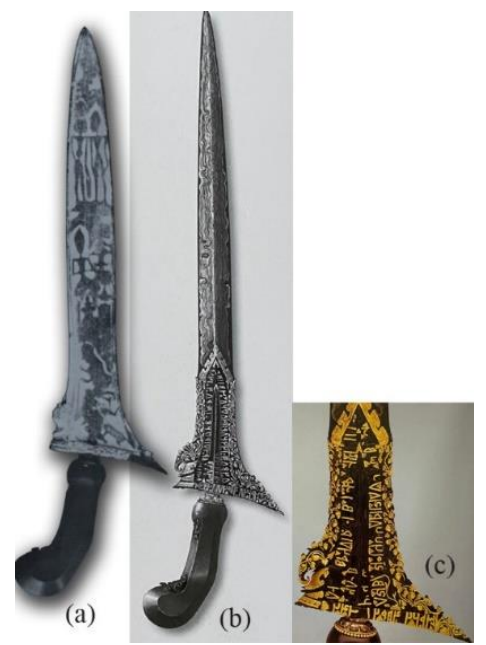

Fig 2. Keris Mintaraga and Keris Rapalan

(a) Keris Mintaraga (Callenfels, 1925:55)[3]

(b) Keris Rapalan (Haryoguritno, 2006:253) [4]

(c) Detail of keris Rapalan (Haryoguritno, 2006:250)[4] 
The expressions of the Keris Mintaraga and the Keris Rapalan look different in blade material and visualization, but they both have similarities i.e.: 1) The Keris Mintaraga describes the existence of the underworld (flora and fauna), the human world (Arjuna and Punakawan), and the supernatural realms (god and goddess) [3]; 2) Keris Mintaraga emphasizes a truth in tattwa, including yoga to achieve virarasa (a sense of heroism) and santarasa (a sense of peace)[19]; 3) Keris Mintaraga depicts Arjuna's powers after meditating with the symbol of the Pasopati arrow which was successfully used to kill the giant Niwatakawaca[19]; 4) Keris Rapalan describes the existence of a union between the present realm and the ancestral realm (in the form of a temple symbolization) as a reminder of God's purpose for creating human beings[20]; 5) Keris Rapalan also depicts the unity between the ruler (symbolized by a crown, ornament on the top) and kawula (symbolized by various Arabic, Javanese, and Dewanagari letters); 6) The keris Rapalan depicts the king's power as not the most important thing in case of a symbolization of the arrow on the ganja (base of the keris blade) which reads 'anyakrawati ambahu dhendha' which means 'rotater of the whoe world and ruler of the law'[20]; 7) There is a discourse about the source of truth, Allah, as encrypted on the wuwungan ganja (lowest part of ganja and visible while the blade is in the sheath); 8) The Keris Rapalan depicts the magic of the Wijayakusuma Flower (a gold ornament attached to an lambe gajah [elepant lips] on the gandhik) as a symbol of a weapon capable of bringing the dead back to life[20].

The peace campaign can be seen in PB III's efforts to remind that soldiers at all levels are gentlemen, not inanimate objects that can simply be used as targets for cannons and rifles, sword slashes, and spear thrusts. All weapons are made well, such as the Ki Jimat cannon. However, this beautiful human work would be a disastrous paradox if it was used to destroy man-made objects themselves, even to kill humans. Whenever possible, what is needed is an heirloom that is able to bring the dead to life, such as the Wijayakusuma flower - as understood by the Javanese - as seen in the Keris Rapalan visualization[16].

When creating Serat Wiwaha Jarwa and Serat Panji, PB III did not experience any problems because the creation of literary works had become a tradition for the king so that it was easy to do. However, when he wanted to make a keris, there was a big obstacle because iron was not available in all of Java, meanwhile, producing any weapons was a Dutch prohibition. Iron, which was hard to find and the prohibition on importing iron began on December 4, 1741. The letter prohibiting the entry of Javanese iron was based on a "goede reeden" or good reason[21].

According to Lombard [12] the absolute prohibition of the iron import was carried out by the VOC immediately after the massacre of the Chinese (1740) which was followed by a series of wars in Central Java until 1742. What PB III did was to keep making Mintaraga keris even though it was with perfunctory materials accompanied by different visualizations[16]. A different visualization appears in the depiction of the call for unity between the rulers and the people. The Keris Rapalan and Keris Mintaraga have similarities in the depiction of the vines motif (called lung krokot). This motif symbolizes the common people, in line with the depiction of Semar's punawakan in Mintaraga's keris which is considered to represent everyday common sense which is contrary to idealistic and philosophical views[17]. The visualization of lung krokot to symbolize the punakawan is also found in Keris Rapalan.

Indonesians still use the keris as a weapon (in war etc.) as well as a part of daily fashion. Some chronicles state that during the war, only a small number of the troops used guns (muskets) and heavy artillery such as cannons[13]. The marvelous of the keris is also recognized by Dutch as seen in Rembrandt's paintings. The first painting tells of Samson who is invulnerable to weapons, he is stabbed in the eye using a keris. In this painting, it appears that a curved keris is held on to the blade and used to stab Samson's eye[22]. The second painting depicts Samson 
sleeping on Delilah's lap and having her hair cut off[23]. In the painting, Samson appears to be wearing a keris tied with a rope and hanging from his waist. Java and the Netherlands are also considered as the highest achievement as Het Land van Rembrandt's phrase: 'Java and Syndics are actually the two best credentials we have'. Java and its healthy friends are VOC's. Rembrandt, as a Javanese devotee, thanked his syndicate, the VOC [9]. Expressions through keris or paintings may be a powerful way for people or parties to choose non-violent ways to improve dispute situations or reduce conflict[2].

\section{Conclusion}

The 80-years Javanese War ended in 1757. Since then, Java has experienced a relatively long period of peace. Behind this situation there was an effort from the agency (Pakuwubono III) which carried out a peace campaign so that the war would stop immediately. The campaign is carried out through cultural channels in the form of awareness through the discourse of gentleman blood. Pakubuwono III tries to convey the message of the cultural trilogy (Kakawin Arjunawiwaha, Keris Mintaraga, and the story of Panji) in the Palihan Nagari incident during the Kahuripan Kingdom (1049) and to make the transformation during his reign (1749-1788). The Keris Rapalan as a transformation of the Keris Mintaraga conveyed the message: first, that all soldiers are actually gentlemen and their blood is very valuable, should not be spilled for unnecessary things. Second, the call to remain united and always remember the Almighty God.

\section{References}

[1] T. Pettersson and M. Öberg, “Organized violence, 1989-2019,” J. Peace Res., vol. 57, no. 4, pp. 597613, 2020, doi: 10.1177/0022343320934986.

[2] G. Peake, C. Gormley-Heenan, and M. Fitzduff, "From warlords to peacelords: Local leadership capacity in peace processes," INCORE Rep., 2004, [Online]. Available: http://www.incore.ulster.ac.uk/research/projects/wlpl/WlplSum.pdf.

[3] P. van Stein Callenfels, "De Mintaraga-basrelief aan de Oud-Javaansche Bouwwerken," in Oudkundige Dienst in Nederlandsch-Indie Vol. 1, 1st ed., Weltevreden: Dutch Indie Oudkundige Dienst, 1925.

[4] Haryono Haryoguritno, Keris Jawa Antara Mistik dan Nalar, 1st ed. Jakarta: Indonesia Kebanggaanku, 2006.

[5] James Clifford, "On Collecting Art and Culture," in The Cultural Studies Reader, 1st ed., S. During, Ed. London and New York: Routledge, 1993, p. 57.

[6] M. Kühn, "Agonistic planning theory revisited: The planner's role in dealing with conflict," Plan. Theory, 2020, doi: 10.1177/1473095220953201.

[7] N. P. Gleditsch, J. Nordkvelle, and H. Strand, "Peace research - Just the study of war?," J. Peace Res., vol. 51, no. 2, pp. 145-158, 2014, doi: 10.1177/0022343313514074.

[8] M.C. Ricklefs, “- Sejarah Indonesia Modern 1200-2004.” Serambi, Jakarta, 2001.

[9] H. Stevens, Dutch Enterprise and the VOC 1602-1799. Amsterdam: Walburg Pers, 1998.

[10] [10] J.S. Furnivall, Netherlands India A Study of Plural Economy, 1st ed. Cambridge: AT The University Press, 1944.

[11] M.C. Ricklefs, Yogyakarta di Bawah Sultan Mangkubumi 1749-1792. Yogyakarta: MataBangsa, 2002.

[12] Denys Lombard, Nusa Jawa: Silang Budaya Jaringan Asia. Jakarta: Gramedia, 2008.

[13] B. Schrieke, "Javanese Warfare and Its Consequences," in Indonesian Sociological Studies Selected Writings of Schrieke Part Two, 1st ed., W. F. Wertheim, J. F. Kraal, C. C. Berg, and R. A. . Bergman, Eds. The Hague \& Bandung: van Hoeve, 1957, p. 494. 
[14] Empu Totok Brojodiningrat, "Pangeran Jimat dan Ki Jimat," 2020.

[15] Claude Guillot, Banten Sejarah dan Peradaban Abad X-XVII. Jakarta: Kepustakaan Populer Gramedia, 2008.

[16] K.G.P.H. Puger, "Surakarta, Kahuripan, dan Pribadi Raja PB III," 2020.

[17] P. van Stein Callenfels, "Panji en Semar," in Handelingen van het Eerste Congres Voor de Taal, Land, en Volkenkunde van Java 25-26 Desember 1919, P.A.A. Prabu Prangwadana, Ed. Weltevreden: Albrecht en Co., 1921, p. 534.

[18] Th. Pigeaud, Literature of Java, 1st ed. Leiden: Springer, 1967.

[19] I. Kuntara Wiryamartana, Arjunawiwaha Transformasi Teks Jawa Kuna Lewat Tanggapan dan Penciptaan diLingkungan Sastra Jawa. Yogyakarta: Duta Wacana University Press, 1990.

[20] Sarjanadipura, "Riwayat dan Makna Keris Rapalan," 2020.

[21] Mr. J.A. van der Chijs, Nederlandsch-Indisch Plakaatboek, 1602-1811 Vierde Deel 1709-1743. 's Hage: Landsdrukkerij \& M. Nijhoff, 1887.

[22] K.H. Corrigan, "Asia in Amsterdam: The Culture of The Luxury in the Golden Age," in Peabody Essex Museum, Yale: Yale University Press, 2015.

[23] J. Bruyn et.al, A Corpus of Rembrandt Painting, 1st ed. Dordrecht: Springer, 1982. 